Caroline S. Rupp*

\title{
What's New in European Property Law?
}

\author{
An Overview of Publications in 2015/2016
}

DOI 10.1515/eplj-2017-0004

\section{Introduction}

The aim of this article is to provide those interested in European property law with an overview of recent publications in the field. It does not wish to focus on just a few selected works - the immersion into the critical analysis of single works is and should remain the domain of the EPLJ's Book Review section -, but to offer information on a more general scale. Grouped by subject matter, a large number of monographs and articles addressing European property law issues is presented. The brief content descriptions and outlines of ideas cannot serve as full meals, but are intended as amuse-bouches to whet the reader's appetite for a more thorough examination, and as digests presenting short summaries of topics addressed and ideas explored. The article's objective is to provide both those new to the field of European property law and seasoned veterans of the discipline with an overview of recent publications that combines popular and easily accessible works with more hidden, rarer gems.

However, practical constraints necessitate a restriction of the scope of this overview. For this reason, only publications that explore property law questions from a truly European angle - for example, harmonization perspectives or EU competences or instruments - will be reviewed while more traditional comparative studies without an overarching European aim will not be included. From each volume and essay collection reviewed, only a few highlights of an exemplary nature can be presented to the reader in more detail. And naturally, those works published in the EPLJ itself are not eligible for what would essentially amount to a "self-review". In terms of subject matter, a middle ground between the approaches of property law as strictly a "law of things" and as a widely understood "law of assets" also encompassing rights and claims has been chosen: while the large field of intellectual property law has been left deliberately unmined, some

*Corresponding author: Caroline S. Rupp, MPhil. (Cantab.), junior professor, Faculty of Law, University of Würzburg, Germany, E-Mail: rupp@jura.uni-wuerzburg.de 
works dealing with aspects at the borders of the traditional Germanic narrow understanding of property law have been included.

\section{Comparative property law}

The most comprehensive work on comparative European property law to date is probably Christian von Bar's Gemeineuropäisches Sachenrecht, the first volume of which was published in 2015. ${ }^{1}$ Building on the knowledge from previous comparative studies, ${ }^{2}$ von Bar and his co-workers have undertaken the monumental task of distilling universal European property concepts and rules from the common lines and principles of the EU member states' national property law models. Merging intimate knowledge of the national systems and their specialities on the one hand with a pan-European perspective on the other hand, the work aims at developing a European system of property law.

To this end, the extensive material collected for each national system is not presented in the traditional country report format, but rather grouped by subject matter: volume 1 deals with the nature of property law and rights in rem, the objects of such legal protection and finally the types of subjective in rem rights. After developing a definition of in rem rights as absolute rights over assets, the notion of the object of such rights is scrutinized. The analysis of the different notions of "thing" on the member state level and the similarities and differences in the classification of "things" in national property law leads to a distinction between "real" and "normative" things, with plots of land as a sub-group of the latter. In order to classify the diverse subjective rights, a distinction between unlimited rights (e.g. ownership) and rights limited by time (e.g. usufruct) or content (e.g. restrictive covenants) is proposed.

From the comparison and contrast of the various national approaches, a glimpse of the outlines of an overarching common European property law system emerges, which at least for the time being remains at a highly dogmatic and theoretical level. However, the study never succumbs to the temptation of glossing over differences between the national property laws when dealing with details and exceptions (for example, in the property law treatment of animals) in the

1 Christian von Bar, Gemeineuropäisches Sachenrecht, Band I: Grundlagen, Gegenstände sachenrechtlichen Rechtsschutzes, Arten und Erscheinungsformen subjektiver Sachenrechte (C.H. Beck 2015, LIX, 859 pp.). - An overview of the core ideas has been published as an article, Christian von Bar, ‘Grundfragen europäischen Sachenrechtsverständnisses' Juristenzeitung (JZ) 2015, 845-859. 2 Christian von Bar (ed), Sachenrecht in Europa: Systematische Einführungen und Gesetzestexte, vol. 1-4 (Rasch 1999-2001). 
interest of producing an overarching general concept. On the contrary, it describes the national peculiarities with great attention to detail, pointing out their interaction, connections and synergies. A multitude of examples illustrates the universal needs of reality underlying the various national legal answers, while extensive footnotes point the reader to the primary sources (with an emphasis on case law) and allow for the work's use as a compendium of the current state of national property law. The sophisticated approach to legal language frequently challenges property law notions (like the distinction between movables and immovables) on the semantic level, showing the importance of precise terminology and clear definitions for a pan-European system crossing not only legal, but also linguistic borders. On the whole, the impact of this monumental work is bound to be considerable on many levels, both as a driving force for the still young domain of European property law and as a contribution to the field of comparative property law.

The current state of comparative property law as a discipline is analysed in an article by Eva-Maria Kieninger. ${ }^{3}$ She explores the role of property law as one of the "stepchildren" of comparative law: while there may be no pressing need for the discipline from a practical or political viewpoint, nevertheless it should be given more prominence. Old issues remain unresolved and new questions arise especially from the divide between civil law ("Sachenrecht") and common law ("property") with their fundamentally different historical roots and legal theory notions when approaching property law questions. From the range of topics encompassed by property law, which is far broader in the common law understanding, through the strong influence of legal realism which has led to a relational conception of property law in the US and Scandinavia, to the discrepancies between the common law's functional approach and the civil law's dogmatic categorization, there is a plethora of issues the close comparative scrutiny of which has been absent so far.

An exemplary instance of European comparative property law is Christian von Bar's article on possession in the EU member states' legal systems. ${ }^{4}$ This brief study questions the nature of possession and detention and highlights the different understandings of "right to possess" that can be found across Europe. The fundamental differences between the national approaches are already apparent on a basic structural level as some national codifications take possession as the

3 Eva-Maria Kieninger, 'Sachenrechtliche Prinzipien und Grundbegriffe als Gegenstände der Rechtsvergleichung' in Reinhard Zimmermann (ed), Zukunftsperspektiven der Rechtsvergleichung (Mohr Siebeck 2016), 139-166.

4 Christian von Bar, 'Die Gegenstände des sachenrechtlichen Besitzrechts in den Rechtsordnungen der Europäischen Union' in Wolfgang Büscher et al. (eds), Rechtsdurchsetzung: Festschrift für Hans-Jürgen Ahrens (Carl Heymanns 2016), 585-598. 
starting point of their property law rules while others place it in the wake of their rules on ownership or even within the context of prescription. These divergences are in turn continued and reinforced on the substantive level of the possession rules' contents. A differentiation hence needs to be made between ownership and other absolute rights which coordinate different rightholders' access to a thing and the right to possess which has a merely objective content - lacking a subjective component and being able neither to charge nor to be charged with another right. The function of this right to possess within property law is to serve as a stabilizing factor in the abstract system of ownership and other "right of rights" ("Recht der Rechte"), connecting it to the factual situation and enabling the abstract rights to be changed according to the needs of reality. This theory is then put to the test by application to different facets of possession like its relationship to the law of obligations, questions of acquisitive prescription and possession-based non-derivative acquisition of title. The findings are surprising in some instances, for example when the owner-possessor-relationship traditionally considered a core area of German property law is re-analysed as a special category of torts or unjust enrichment law - and illustrate that the current trend of approaching classic questions of property law from the new angle of possession leads to fruitful results and new impulses for debate.

\section{European Union property law}

It is often postulated that property law remains one of the fields of private law still widely reserved for the national level without interference by the European Union. Nevertheless, in the past decade or so various suggestions have been made for an intensified Europeanization of property law - leading to questions not only on the substantive level, but also concerning the underlying fundamental issue of regulatory competence in property law matters.

This latter question is approached by Bram Akkermans from a constitutional law angle. ${ }^{5}$ Property law forms not only a part of private law, but also has a strong constitutional law component as it provides individually protected rights and, more generally, forms a cornerstone of the social market economy. As a working system of property law is essential for the functioning of the internal market, the possibility of a regulatory competence for property law at the EU

5 Bram Akkermans, 'European Union Constitutional Property Law: Searching for Foundations for the Allocation of Regulatory Competences' in Bram Akkermans/Jaap Hage/Nicole Kornet/Jan Smits (eds), Who does What? On the allocation of competences in European Private Law (Intersentia 2015), 177-210. 
level is not to be dismissed out of hand: in case the interplay between the various national private law conceptions and their changes adversely affects the internal market, the resulting instability may necessitate legislative action by the EU itself. Developing and defining what "European economic constitutional law" means, Akkermans sketches the current situation of property law in the internal market. Within the framework of the general constitutional order of the EU, the legal systems of the member states and the EU itself interact, with the EU extrapolating its property law rules from the national laws while in turn influencing their development. In order for this model to work, both the regulation of the essentials of the market economy at the EU level and the individual member states' legal systems have to function. This is illustrated by the hypothetical scenario of a member state returning to socialism or another planned economy model: such a fundamentally different approach to property law by one member (abolishing, for example, the free circulation of goods) would lead to grave problems for the internal market as a whole.

A closer scrutiny of property law rules in the EU shows that a distinction can be drawn between the general "organisational rules" embedding property in society and the market order and "transactional rules" governing the practical and technical aspects of its everyday application. While the first group belongs to constitutional law and its rules are provided by both national and EU constitutional law, until now the second group belonging to private law has been almost exclusively dealt with at the national level. Conflicts resulting from differences between the national sets of rules can be solved through the corrective mechanisms of EU economic constitutional law, by preventing the application of those national rules which hinder the market access and/or free movement guaranteed by the EU. However, the drawbacks of this model (e.g. its high transaction costs) lead Akkermans to suggest a rethinking of the current competence division. Inspired by current developments in South African law and taking into account the wider constitutional law context, he develops a multi-dimensional and multilevel model of regulatory competence: while the EU should provide a framework of constitutional principles guiding the detailed regulatory decisions of its member states and individuals, in keeping with general principles of federalism regulatory action should be allocated to the lower national level unless EU legislation is necessary for the functioning of the internal market.

These issues are also touched upon in Jürgen Basedow's analysis of the development of the right of ownership in the EU. ${ }^{6}$ After a look at the various facets

6 Jürgen Basedow, 'Die Entwicklung des Eigentumsrechts in der Europäischen Union’ Zeitschrift für Europäisches Privatrecht (ZEuP) 2016, 573-590. 
of ownership - as part of private law, as a socio-political instrument for the allocation of resources, and as a feature of the market economy -, he turns to the oft-quoted Art. 345 TFEU and its various (mis)interpretations, construing it not as a general "competence blockade" for the EU but merely as a limit for specific actions such as the nationalization of entire branches of industry. The article then considers the existing EU regulations concerning ownership. The primary EU law level presents an example of the typical fragmentary situation of EU private law. Lacking a general competence for "ownership matters", the EU can only regulate those selected ownership issues that fall within the context of its functional regulatory competences - in practice the establishment and functioning of the internal market (Art. 114 TFEU) and the judicial cooperation in civil matters having cross-border implications (Art. 81 TFEU). This leads to a European approach to ownership rules driven by the functioning of the market rather than by the understanding of ownership as a protection of legal title that the member states take as a basis.

The secondary EU law also lacks coherence so far. The strongest tendency for Europeanization can be discerned in intellectual property law, where various European rules and instruments (for example, the optional European patent or the harmonization of the national trade mark laws) have been implemented - but still, large gaps remain to be filled by the member states' law. Concerning security rights, Basedow criticizes the ECJ's ruling that although the 2000 Late Payments Directive has introduced EU-wide rules on the retention of title, its third-party effects are still to be subject to national law which effectively dashed the hopes for a more far-reaching harmonization of substantive law. At least the competence question regarding security rights has come to the forefront of attention with the ratification of the Cape Town Convention's Aircraft Equipment Protocol by the EU. Finally, the need for exceptions regarding ownership rights in insolvency scenarios has been recognized in the 2015 Insolvency Proceedings Regulation. Throughout, the internal market can be identified as the driving force behind the EU's regulatory actions. Basedow concludes that while a market-connected regulatory competence at the EU level can be postulated, a general concept of ownership is still lacking and that currently, instead of a harmonization of substantive law, Europeanization at the private international law level appears more promising.

The possibilities of such a harmonization of private international property law are sketched by Eva-Maria Kieninger. ${ }^{7}$ Although political attempts in this

7 Eva-Maria Kieninger, 'Das internationale Sachenrecht als Gegenstand eines Rechtsakts der EU eine Skizze' in Katharina Hilbig-Lugani et al. (eds), Zwischenbilanz: Festschrift für Dagmar Coester-Waltjen (Gieseking 2015), 469-484. 
direction have not been made yet either at the EU level or on a world-wide scale, the high relevance for the internal market should allow for a European regulatory competence based on Art. 81 para. 2 lit. c) TFEU. Kieninger proposes the harmonization of conflicts rules through an EU regulation, potentially flanked by directives concerning selected aspects of substantive law. While she advocates the general application of these harmonized private international law rules as loi uniforme, she suggests restricting their scope to a more narrow understanding of "property" as tangible objects only in order to avoid difficulties of qualification. As potential models, various national examples are analysed, especially regarding their use of the lex rei sitae. While the situs rule still prevails in Switzerland and the Netherlands, its application has been clearly delimited and exceptions have been allowed for, showing a tendency towards a choice of law but not unlimited freedom of choice. Meanwhile, the new codifications of Poland, Romania and the Czech Republic are providing a variety of solutions ranging from the traditional to the innovative - which still have to prove their worth in practice. Finally, the 2007 UNCITRAL Legislative Guide on Secured Transactions offers suggestions concerning security rights, albeit limited to movables.

From these examples, Kieninger synthesizes guidelines for harmonized private international property law rules. The basic rule in a European private international property law system should still be the situs rule as a general choice of law model would prove detrimental for third parties. While this should be applied to immovables without exceptions, the scope and reach of the application to movables should be clearly demarcated and exceptions provided for registered means of transportation, res in transitu and export goods. Nevertheless, even with such a harmonization of private international law rules, the main problem of a change of the applicable law when things cross borders remains. It can be overcome only by harmonization on the substantive property law level or the introduction of a supranational legal instrument, for which Kieninger advocates a notice-filing approach. Such a European harmonization on the substantive law level would then allow for the mutual recognition of property rights, practically enabled on the private international law level by a grace period model.

\section{Movable Property}

In the field of movable property law, the most prominent topic remains the possibility of harmonization concerning security rights in movable assets. Its exploration from various angles has continued in the past two years. 2015 has seen the publication of the long-awaited volume on Proprietary Security in Movable 
Assets $^{8}$, part of the Study Group on a European Civil Code's Principles of European Law series. Following up on the Principles and Comments in the 2009 full edition of the Draft Common Frame of Reference (DCFR) ${ }^{9}$, this new volume offers further extensive information on the rules on proprietary security in Book IX DCFR. The text of the DCFR articles itself is presented in five languages with suggestions for alternative wordings in instances where since the DCFR's initial publication a need for change has been discovered. The introduction provides the reader with an overview of the aims and functions of security rights, recent international developments and the general characteristics of Book IX DCFR, placing it both within the context of the DCFR and within the world-wide field of international property law. The black-letter rules of the seven chapters of Book IX DCFR are then elaborated upon in great detail, with Comments and National Notes providing background information on the various national solutions to the questions addressed by the DCFR's rules as well as on the considerations that motivated their formulation and adoption in the DCFR. This will prove especially valuable concerning the notice-filing approach chosen by the DCFR as a publicity feature: while in conformity with a general current trend of development, notice-filing registration is still a concept unknown to many European national property law systems. The detailed background information provided on the rules will serve a better understanding of their functioning and the reasons behind their adoption, leading in turn to a higher acceptance of this relatively new registration model.

Rounded off by a comprehensive bibliography, a general index and jurisdiction indices, the volume offers new approaches and insights for property law comparatists from academic as well as practical backgrounds. The combination of detailed information on the national solutions currently in force and suggestions for further development and harmonization will provide valuable input for ongoing and future reform projects on both the national and supranational level. Of course, the volume also greatly facilitates detailed work with the rules of Book IX DCFR themselves. The special attention paid throughout to the reforms concerning security rights in movables which have been implemented in various European member states in the past few years shows that the DCFR project is not static but itself developing along with its component national laws. In inspiring and motivating further work towards a European harmonization of security rights in movables, this volume provides an important milestone.

8 Ulrich Drobnig/Ole Böger, Proprietary Security in Movable Assets (PEL Prop. Sec.) (Sellier 2015, LVI, 934 pp.).

9 Study Group on a European Civil Code/Research Group on EC Private Law (Acquis Group) (eds), Principles, Definitions and Model Rules of European Private Law: Draft Common Frame of Reference (DCFR) Full Edition, vol. 1-6 (Sellier 2009). 
The current "state of the union" concerning the long-standing question of a harmonized European security right in movables is presented in a 2016 article by Eva-Maria Kieninger. ${ }^{10}$ The dangers for the internal market arising from the "discontinuity" of national property laws, fuelled by both the differences in substantive law and the strict application of the situs rule, still remain the same as at the outset of the debate, while various possible solutions present themselves. Harmonization on the private international law level by a European international property law regulation replacing the situs rule with free choice of law has been advocated by some - but this approach is shown to have various weaknesses. As in the majority of cases, the location of an asset is neither fortuitous nor unstable, the lex rei sitae should remain in force. The need for European harmonization should rather be approached by minimizing the current differences between the national legal systems through either harmonization on the substantive law level or the introduction of an optional European security right. While an optional instrument would provide an easier and quicker solution, a directive establishing the member states' duty to harmonize their national security rights and recognize the security rights established in other member states would prove more fruitful in the long run.

In both instances, the main problem presenting itself is the publicity issue as the national solutions differ strongly in this regard. For example, the German transfer of ownership for security purposes is frequently criticised and often not accepted as valid due to its non-publicity. On the other hand, the registration of liens meets with scepticism in Germany as the common German understanding of registration is that of the complex and time- and cost-intensive immovables registration in the Grundbuch which is not suitable for security rights in movables. Taking into account the nature of security rights in movables, the need for a registration system able to easily identify individual assets, adapt to changes both of the asset(s) used for security purposes and the security right itself and strike a balance between the cost and effort and the value of the security arises. Like Book IX DCFR, Kieninger proposes a notice-filing approach based on the US-American model. Rather than reliably mirroring each change of the actual situation (in the sense of the Grundbuch's positive publicity), such a registration system would serve primarily to solve priority conflicts between rightholders - this less farreaching effect allows for uncomplicated use mechanisms and speedy procedure. On the European level, a notice-filing model might be implemented as a compromise between current national publicity systems.

10 Eva-Maria Kieninger, 'Perspektiven für ein Europäisches Mobiliarkreditsicherungsrecht' Zeitschrift für Europäisches Privatrecht (ZEuP) 2016, 201-214. 
A bottom-up approach for the harmonization of security rights in Europe is proposed by Willem Loof and Anna Berlee. ${ }^{11}$ Their comparative case study approaches the question from the angle of the tension between two groups of secured creditors, namely financiers (i.e. banks) and suppliers whose interests conflict especially in insolvency scenarios. Offering financiers the possibility of encompassing security rights on all assets (including future assets) threatens to shut out suppliers whose security options become severely limited. It is the legislator's policy choice to prefer or protect either group and to strike or shift the balance between their security right options. The comparison of these national policy choices allows insights into the need for regulation at the European level: when similar political choices are implemented through differing national techniques, harmonization at the EU level is desirable in order to simplify the technical approach while retaining the already existent balance of interests. On the other hand, attempting the harmonization of fundamentally different policy choices would prove problematic.

In order to establish the necessary regulation level for security rights in movables, the authors scrutinize the solutions chosen by Dutch, English and Belgian law after recent reforms and debates as well as the model laws in Book IX DCFR and Art. 9 Uniform Commercial Code (UCC). Non-possessory security rights are a central need especially in the commercial context - and the development of the traditional pledge model towards a non-possessory security seems to meet with general acceptance. On the other hand, the transfer of ownership for security purposes has been abolished in the recent reforms in both Belgium and the Netherlands, and the retention of ownership, especially in its extended forms, is also meeting with increasing resistance. Registration questions come to the forefront both on the continent and in the context of the English (fixed and floating) equitable charge. While a shift towards favouring the financier group of creditors can be discerned in the Netherlands and the same tendency remains upheld in England, the system implemented by the 2013 Belgian reform offers fairly equal positions to the financiers and the suppliers through the functional similarity of pledge and reservation of ownership. On the whole, all systems explored make a similar policy choice allowing the financier to take a general security while suppliers are provided with "super priorities" at least on the goods supplied by them. The authors conclude from this that harmonization is advisable regarding the security rights for financiers - either retaining the national supplier rights or

11 Willem Loof/Anna Berlee, 'Case Study: Harmonizing Security Rights' in Bram Akkermans/ Jaap Hage/Nicole Kornet/Jan Smits (eds), Who does What? On the allocation of competences in European Private Law (Intersentia 2015), 211-244. 
harmonizing these as well. Instead of a top-down harmonization through binding EU instruments, they advocate a functional bottom-up approach through a model law, which might stem from a source other than the EU institutions.

The comparative analysis of security rights was also the central topic of the civilian section of the German Society for Comparative Law (Gesellschaft für Rechtsvergleichung) at its $34^{\text {th }}$ convention in 2013. ${ }^{12}$ National reports from seven countries shed light on the different functions of in rem rights, concentrating on the conflict between the protection of the rightholder and/or beneficiary on the one hand and that of others, e.g. acquirers of rights or insolvency participants, on the other hand. While Spain and Germany still adhere to their traditional property law models, in Hungary and France recent reforms have introduced momentous changes to the system of security rights - for example, the abolition of the transfer of ownership for security purposes in favour of the newly introduced registered non-possessory pledge in Hungary. Although no far-reaching legislative changes have yet been introduced in Italy, strong lines of development can be traced in recent case law and practice. Non-European input is provided by the contributions on South African law which traditionally follows a register-centred approach, and Chinese law which has introduced a hybrid model of security rights. Throughout, the question of publicity is - once again - identified as the central issue, with diametrically different national tendencies in the approaches to registration. Especially in the Romanic legal systems, trust constructions emerge as increasingly popular alternatives to the traditional security models of pledge and transfer of ownership.

A comparative study dedicated to the international dimension of the retention of ownership has been published by a group of authors from the Rijksuniversiteit Groningen. ${ }^{13}$ It does not approach this popular security right from the overarching bird's eye perspective of harmonization, but rather through its practical application in legal relationships between the Netherlands and its four main trading partners in the EU (Belgium, Germany, England and France). Following the same structure, the substantive law of each country is presented with its main characteristics and peculiarities (like e.g. the English "tracing" or the German "Verarbeitungsklausel"), followed by an overview of the applicable private international law with its specific concerns (e.g. conflit mobile, renvoi). Each chapter then explores the scenarios that an asset subject to a Dutch retention of ownership right is exported to the respective country and that an asset subject to the

12 Martin Gebauer/Stefan Huber (eds), Dingliche Rechtspositionen und Verkehrsschutz: Kontinuität und Reformen in vergleichender Perspektive (Mohr Siebeck 2015, 185 pp.).

13 F.J.L. Kaptein/J.G. Knot/R. Koolhoven/D.F. Kopalit/E.F. Verheul/F.M.J. Verstijlen, Het internationale eigendomsvoorbehoud (Wolters Kluwer 2015, XIV, 186 p.) 
foreign retention of title right is imported to the Netherlands. Rounded off by the potential difficulties arising in insolvency situations, these country reports offer detailed information on the current state of the law in each country which is especially useful from a practitioner's perspective. On the comparative level, the study restricts itself to the exploration of bilateral scenarios from a Dutch point of view. While European property lawyers may miss more general comparative conclusions from the synthesis of these results, that is not the aim of this volume. Its illustration of the application of property law to cross-border relationships from a national viewpoint may nevertheless serve as a basis for further European developments, as these need to build on the member states' experiences and insights and take into account their peculiarities.

In addition, 2016 has seen the publication of a PhD thesis concerned with international questions of movable property law not related to security rights. ${ }^{14}$ Max Finkelmeier explores the international dimension of the German rei vindicatio restitution claim ( $\$ 985$ BGB) and the concurrent claims from the relationship between the owner and the possessor of a thing. On the private international law level, he advocates a uniform autonomous qualification for this core area of German property law and develops a new functional and comparative qualification method consisting of several steps. To this end, he subjects each claim to a detailed comparative analysis, with the continental Roman law-based approach represented by French and Dutch law, the more torts-oriented understanding of the common law represented by English law, and the DCFR as an example of a supranational compromise solution. His functional analysis illustrated by exemplary case constellations takes into consideration the difficulties of definition when delimiting the various claims ("Randbereichskonkretisierung") as well as the differing interests from the private international law angle. Finkelmeier's resulting propositions for the qualification of the rei vindicatio and its related claims are surprising from a traditional German point of view: while he favours a property law qualification for the rei vindicatio claim itself, he suggests a torts qualification for the related claims for damages, an unjust enrichment qualification for the claims for reimbursement for outlays, and a mixed torts/unjust enrichment qualification for the emoluments claims. While remaining grounded in the traditional dogmatics of German property law, he develops it further by relating it to other national solutions and shedding light on the interplay between national and European private international law rules. Although his approach in this work is specifically tailored to this very specific field of German property law, his metho-

14 Max Finkelmeier, Qualifikation der Vindikation und des Eigentümer-Besitzer-Verhältnisses (Mohr Siebeck 2016, XXX, 450 pp.). 
dology may be adapted to suit other questions of property law and possibly develop a more general conflict of laws model.

\section{Immovable Property}

The past two years have seen an impressive number of publications concerning immovable property. The discipline of land law, which in the past has frequently been considered an unwieldy topic not lending itself to fruitful comparative and European work, has gained more and more popularity on an international scale. The vigorous exploration of various aspects of immovable property law from a European viewpoint has led to several in-depth publications which highlight not just the differences between national land law systems but offer suggestions for future developments and possible harmonization approaches.

Land lawyers across Europe will profit highly from the updated and extended second edition of the Handbuch Immobilienrecht in Europa. ${ }^{15}$ Aimed primarily at practitioners (e.g. notaries), the handbook offers a comprehensive overview of the status quo of land law in 23 countries reflecting the European immovables market - including Norway, Switzerland and Turkey as well as the main EU member states. It approaches the complex subject from the practice-oriented point of view of the questions arising when land is bought, owned, sold or bequeathed, dealing with aspects of registration, financing and tax as well as succession law issues. One of the great merits of this work is that in spite of the fundamental differences in the national conceptions and regulations of land law, all country reports follow the same structure and subdivision, allowing for quick referencing and direct comparison of the national approaches further facilitated by an extensive index.

In each country report, a brief introduction embeds land law in the general context of the national political, economic and legal system and sketches the notarial system and the formal requirements for land transactions. The basic structures and principles of land law are then presented, with an overview of the different types of rights in land, the function and effects of land registration, sales contracts, special types of contracts (e.g. developer contracts), and issues of financing, powers of attorney and tax in both national and cross-border scenarios, rounded off by information on the treatment of land in succession cases. In a

15 Susanne Frank/Thomas Wachter (eds), Handbuch Immobilienrecht in Europa: Zivil- und steuerrechtliche Aspekte des Erwerbs, der Veräußerung und der Vererbung von Immobilien ( $2^{\text {nd }}$ edn, C.F. Müller 2015, VII, 1870 pp.). 
very condensed space, a plethora of detailed information is offered, for example on the intricate French special regulations for sales contracts with developers (vente d'immeuble à construire) or national regulations for the preservation of historical monuments. For each country, an annex contains further materials as well as sample texts for register entries, sales contracts, security rights contracts and powers of attorney both in the respective country's official language and in German. Due to the large scope and practical aim of the handbook, the discussion of theoretical questions is restricted to a minimum with extensive references allowing for their further exploration. Whether in dealing with the more technical aspects of cross-border immovables transactions or as a starting point for more theoretical comparative research, the updated handbook will prove an invaluable companion for practitioners and academics alike.

A practice-oriented approach to land law has been provided for more than a decade by the Round Table on security rights over real property in Europe: their publication series of more than 50 volumes ${ }^{16}$ offers detailed information on security rights in land from various national angles as well as from a comparative perspective. The Round Table's objective is to comparatively assess security rights from an economic point of view, providing practitioners and academics with systematized information on the different security rights models. To this end, by means of functionally oriented questionnaires, information on national security rights is collected, systematized comparatively and visualized in charts offering geographical overviews of the different structures, tendencies and policy choices, with an assessment of their respective economic benefits. This innovative methodology faces the challenge of combining the very diverse dogmatic backgrounds of the national models into a more general questionand-answer-scheme, but reaps the reward of providing rapid access to simultaneous information on the approach to central issues in many legal systems. Having developed its own IT system to process and store the ever-growing information collected, in 2016 the Round Table met for its $20^{\text {th }}$ workshop with by now 37 members.

In celebration of this event, a collection of essays has been published presenting the Round Table's work and featuring contributions by its renowned national members on current questions of security rights in land. ${ }^{17}$ Three articles on the

16 An overview of the publication series can be found under https://www.pfandbrief.de/cms/_in ternet.nsf/tindex/de_66.htm?OpenDocument\&51FB6696AFF373DFC125754600396092 (last accessed on January 5, 2017).

17 Tim Lassen/Andreas Luckow/Mario Thurner (eds), Grundpfandrechte 2016 in Europa und darüber hinaus: Eine Standortbestimmung zum XX. Workshop des Runden Tisches Grundpfandrechte (Verband Deutscher Pfandbriefbanken 2016, 214 pp.). 
Round Table itself present its working system and methodology, highlight the experiences from its development and shed light on the challenges that the task of providing legal monitoring for banks presents. The reports in the following section trace recent developments on the national level, covering a wide range of aspects. Some of them address ever-burning questions, like Hans Fredrik Marthinussen's contribution on who should benefit from the "free parts" of non-accessory security rights from a Norwegian perspective (pp. 121-128). Others present new legislative developments like Kurt Haefeli's article on the Swiss revision of land securities law (pp. 141-149), Dimitrios-Panagiotis L. Tzakas' essay on the creditor's position in foreclosure and insolvency proceedings under the new Greek laws (pp. 85-92), or Meliha Povlakić's remarks on the non-accessory security right newly introduced in Bosnia-Herzegovina (pp. 59-66). The Croatian transfer of ownership for security purposes presented by Tatjana Josipović (pp. 101111) and the fiducia of the new Romanian Civil code outlined by Adrian Stefan Sacalschi (pp.137-140) offer alternatives to the traditional mortgage model. These insights into national developments and tendencies are rounded off by a final section introducing the Round Table's activities in the related fields of commercial property owned by property holding companies and property-equivalent rights like building ownership or condominium rights. Offering glimpses into many questions currently afoot in the field of security rights in land and the multitude of solutions suggested by the different national legal systems, this volume is both a milestone in the Round Table's work and an appetizer for its future projects and publications.

The author of these lines has herself published a $\mathrm{PhD}$ thesis on security rights in land. ${ }^{18}$ After the recent financial crisis, earlier projects for a "Eurohypothec" have been momentarily abandoned on the political level - but more than ever, a common European security right in land could provide a valuable tool to facilitate cross-border immovables transactions in the internal market. However, it is time to reassess the basic principles on which to base such a Eurohypothec, as the crisis has shifted attention towards the protection of debtors and the non-accessory German and Swiss security rights previously considered the ideal models for a Eurohypothec have recently undergone extensive reforms. My thesis hence starts with a description of the current design of security rights in land in five continental European countries (Germany, Austria, Switzerland, France and Italy), focusing especially on the link between the security right and the secured claim in the various phases of the security right's life cycle. From a comparative

18 Caroline S. Rupp, Grundpfandrechte zwischen Flexibilität und Schutz (Mohr Siebeck 2015, XXVI, 746 pp.). 
perspective, it can be concluded that the oft-quoted fundamental structural difference between accessory and non-accessory security rights does not lead to huge practical discrepancies in the functioning of the security rights after all, as the results achieved automatically by the dogmatic rules of accessory securities are normally constructed contractually for non-accessory securities as well and the traditional restrictions of accessory securities can largely be overcome by modern and more flexible interpretations of the principle of accessoriness. Hence, I suggest that an accessory security right in land based on the traditional hypothec model from Roman law and designed to fit the needs of the $21^{\text {st }}$ century will provide the best basis for a modern land security right for all of Europe. This should be rounded off by a registration system allowing for an easily accessible yet reliable form of publicity, while the economic needs of commercial actors can be accommodated by special rules allowing for a more versatile use and faster transmission of the security right.

Land registration has long been regarded an issue hardly worthy of comparative research due to the national nature and scope of registers. However, as the differences between the nature and effects of registration in its member states pose an increasing challenge for the EU, a need for an international approach to land registration law is emerging. One of the first publications in this field is a collection of essays focusing on the role and aims of land registration systems in modern Europe ${ }^{19}$ - resulting from an ongoing research project devoted to the comparative analysis of national land registration systems from a functional perspective and aimed at developing guidelines for uniform European standards for registration. 27 articles shed light on the register's manifold functions as an instrument of information, systematization, legal development and protection and highlight current issues in land registration such as digitalization or the conflict between publicity and privacy protection.

Part I deals with the register's place within the legal system on the national (e.g. Peter Bydlinski's contribution on the formal requirements of immovables transactions in Austria, pp. 153-169), comparative (e.g. Arkadiusz Wudarski's observations on the German and Polish land registers, pp. 23-81) and international level (e.g. Peter Mankowski's article on land registration in private international law and international civil procedure, pp. 83-100). Part II is devoted to the organization of the register's contents, bringing together various national experiences like the role of possession in English land registration (Mark Jordan, pp. 221-238) or the registration of pre-contracts in Italy (Riccardo Omodei Salè,

19 Arkadiusz Wudarski (ed), Das Grundbuch im Europa des 21. Jahrhunderts (Duncker \& Humblot 2016, 783 pp.). 
pp. 269-285). Different national answers to the central question of the extent of protection of public faith in the land register are presented in Part III: traditional solutions from the Germanic (Austria, Romana Cierpial-Magnor and Arkadiusz Wudarski, pp. 287-313) and Romanic (Spain, Javier Gómez Gálligo, pp. 341-369) legal traditions are presented as well as the more recent models of the English Land Registration Act 2002 (Emma Lees, pp. 371-393) and the new Czech Civil code which reintroduced the principle of good faith in publicity (Eva Dobrovolná and Artur Barański, pp. 315-340). Further aspects of the potential scope and limits of good faith protection are explored by Kenneth G.C. Reid's insights on the Scottish land registration system (pp. 395-412) and Vincent Sagaert's presentation of the Belgian register's negative and positive effects (pp. 413-425). Part IV highlights new tendencies and recent reforms of land registration systems in various European countries like Cyprus (Tatiana-Eleni Synodinou, pp. 533-550) or Romania (Eugen Chelaru, pp. 429-445). Some of the challenges that a modern economic environment poses for land registration are presented in the final Part $\mathrm{V}$ which combines technical aspects like digitalization (Harald Wilsch, pp. 705728) with more fundamental questions like Julien Dubarry's analysis of the relationship between the land register and general principles of property law in France (pp. 617-636).

Bringing together both practical issues like the link between land register and cadastre or the role of state officials in land registration and more general dogmatic problems like the balancing of opposing interests, the volume illustrates both the obstacles and the achievements on the way to a more European understanding of land registration law. One of its many merits is that it does not restrict itself to the land registration traditions of Western Europe, but incorporates the experiences of Eastern European countries throughout. These provide a valuable mine of information for European land lawyers, whether in the lessons learned from the reforms necessitated by the transformation process (e.g. in Croatia, Tatiana Josipović, pp. 239-268), or concerning the unification of fragmented systems as exemplified by Romania or Bosnia-Herzegovina (Meliha Povlakić, pp. 495-532). The expertise gained from these recent developments could serve to guide the European integration process as well.

The Trento Common Core of European Private Law research group has published two volumes dealing with aspects of European land law. Both follow the Common core case law method of comparative analysis through case studies: typical scenarios are outlined in exemplary cases to which the different national solutions (structured into operative rules, descriptive formants and metalegal formants) are presented, summarized by comparative remarks on each case while extensive legislation tables, indices and bibliographies provide the reader with additional background information. 
Edited by Sonia Martín Santisteban and Peter Sparkes, Protection of Immovables in European Legal Systems ${ }^{20}$ explores the possibilities of landowners to protect themselves legally against the occupation of their land by squatters, former tenants, etc.. Many of the actions available for these scenarios today can be traced back to their roots in Roman law, like vindication or possessory remedies - Frits Brandsma sketches both their historical origin and their development in the ius commune (pp. 9-30). In the course of the $20^{\text {th }}$ century, their effects have however been tempered by the influence of human rights law, as the fundamental rights of the individuals concerned may intervene in private law relationships as Sandra Passinhas' analysis of the ECHR case law in immovables protection cases shows (pp. 31-63). The practical application of these principles in 14 European jurisdictions is then investigated in 12 case studies covering issues such as actions against forcible intruders, unknown protesters, or former tenants, the permissibility of owner's self-help, adverse possession and nuisance. The overview of the variety of remedies that the national laws provide to balance opposing interests and solve conflicts between owners and "users" of land shows that in many constellations, practical questions need to be considered as well as the theoretical underpinnings of property law, and stresses the increasingly important role of land registration in finding fair solutions.

While of high relevance in everyday legal practice, condominium law has not been in the focus of comparative law until the publication of the Common Core volume European Condominium Law. ${ }^{21}$ With varying names and concepts like apartment ownership, commonhold or horizontal property, today most European legislations allow for the ownership of parts of or shares in immovables. By way of introduction, Cornelius van der Merwe sketches the development of this fairly recent instrument and outlines its basic principles. While the condominium idea manifests itself in manifold forms (some of the more obscure being the "dockominium" of yacht mooring spaces or graveyard site condominium), in all of them by-laws and house rules play a central role in coordinating the rights and duties of those participating in the condominium scheme and ensuring its internal harmony. Building on these findings, 10 case studies illustrate the most pertinent issues arising in condominium scenarios, from the initial question of unit purchase while the condominium complex is still in its building phase to the need for the modernisation or termination of an outdated condominium scheme. Many of these are of a practical nature and touch upon social questions, like restrictions of

20 Sonia Martín Santisteban/Peter Sparkes (eds), Protection of Immovables in European Legal Systems (Cambridge University Press 2015, XXXV, 497 pp.).

21 Cornelius van der Merwe (ed), European Condominium Law (Cambridge University Press 2015, XLIV, 644 pp.). 
the owner's power of disposal through potentially discriminating sale or letting prohibitions, the coordination of conflicting interests of use and enjoyment within the condominium community, or the content and enforcement of by-laws. The answers to these questions are provided in country reports from 21 jurisdictions covering Europe from Catalonia to Norway as well as South Africa and preceded by comparative summaries providing the reader with a general overview. A conclusive review highlights recent developments and points to further possibilities for comparative investigation. This first comparative study of condominium law is a prime example of the interplay of law and social considerations, offering new perspectives on traditional questions and categories of property law like e.g. ownership. Its lively presentation of the highly statute-driven and often technical area of condominium law through the pragmatic lens of real-life difficulties and with a sense for the human drama, but also humour that unfolds within condominium communities will hopefully lead to greater attention to European condominium law in the coming years.

\section{Miscellaneous}

Although published already in 2014, John G. Sprankling's The international law of property $^{22}$ merits inclusion in this review. Rather than approaching property law questions through the comparison of various national models according to the traditional view of property law as a largely municipal domain, this study explores the increasingly emerging property law issues and influences above and beyond national or regional borderlines. In its Part I "Foundations", the development and outlines of an international concept of property are delineated: while a definition at the international level is still lacking, the need for a common global understanding of property becomes imperative e.g. in the context of human rights. From a broad understanding of property rights as "an entitlement of a person that is related to a thing”, Sprankling roughly classifies both the possible types of rights (e.g. ownership or security interests) and the objects these rights can refer to.

Part II "Components" turns to a number of subject areas in which international doctrines of property rights can be discerned, exploring the facets of creation, protection, harmonization, restrictions and prohibition of rights in each of them. The transboundary nature of property law objects and relationships often

22 John G. Sprankling, The International Law of Property (Oxford University Press 2014, XLII, 380 p.). 
necessitates regulation on an international level, both for tangible objects (e.g. contraband, wild animals and plants or objects owned by diplomats or intergovernmental organizations) and for intangibles (e.g. genetic material or arbitral awards). Regarding property rights in land, ethical considerations come to the forefront with the strong impact of human rights and the need to protect vulnerable groups. The situation of a "global commons" where national jurisdiction is non-existent and only international law can provide rules for the coordination of conflicting interests presents additional challenges, as can be seen in Antarctica or the high seas but also when considering property rights in outer space. As resources like fresh water become more and more scarce, traditional individual rights of ownership or exploitation need to be curbed in order to preserve natural resources, while new forms of property like digital property or emission allowances need to be given legal shape. While in some subject areas, international treaties have superseded national law, a general need for further harmonization is evident.

Part III “The Global Right” questions inhowfar a global right to property can be distilled from human rights conventions, general principles of law and customary international law. It scrutinizes such a generally applicable right from its various angles as a right to acquire, use, destroy, exclude others and transfer, showing the scope and exceptions of possible international property rules. In the final section Part IV "Outlook", Sprankling identifies the most pressing issues of the future development of international property law. With diverse actors and their respective agendas, an integrated international property law system seems both a necessity and a dream. Drawing inspiration from various sources and implementing social and environmental considerations, the development of global minimum standards may provide an instrument for further harmonization. The driving force behind such a project must however be the practical application of international property rules.

An approach to dogmatic property law questions from an unusual perspective can be found in Jan Lieder's study on succession in title. ${ }^{23} \mathrm{He}$ analyses various mechanisms of transferring assets provided by German law, including among others the assignment of claims and the transfer of ownership in movables and immovables. Carving out general principles and structures of legal succession, such as the freedom of transfer or the authority to transfer and their respective

23 Jan Lieder, Die rechtsgeschäftliche Sukzession: Eine methodenpluralistische Grundlagenuntersuchung zum deutschen Zivilrecht und Zivilprozessrecht sowie zum Internationalen und Europäischen Privatrecht (Mohr Siebeck 2015, XXXVI, 1296 pp.). 
limits, his work highlights both the parallels and the differences between the normative complexes attributed by German law to the law of obligations and the law of property. It then moves to the procedural level, looking at the consequences of legal succession for civil procedure, for example when the asset transferred is the object of pending litigation or a final judgment. An international dimension comes into play in two regards: firstly, private international law questions in cross-border transfer scenarios are scrutinized and replacing the lex rei sitae with free choice of law is advocated for the transfer of movables (pp. 1025 et seq.). Secondly, the principles of the European model of transfer of ownership in the DCFR are subjected to a critical analysis. While the main focus of the work remains the in-depth analysis of dogmatic questions of German law, its European connections are considered as well as its historic roots. The comprehensive approach sheds light on property law instruments within a more general private law context, offering yet another building block for European private law.

New impulses for property law in general can be derived from cultural property law. Although it necessarily restricts itself to a specific group of individual, highly valuable assets and the particular conflicts arising from their "displacement", at its core, its issues are property law questions with an invariably international dimension. The scope of this article cannot do justice to the recent developments in the field of cultural property law, but merely briefly present some highlight publications which shed interesting light on property law dogmatics. Questions of the art market and its legal framework in the EU are explored in a conference volume ${ }^{24}$ which explores the foundations of the rules of the art market and the interplay of diverging interests and factors in their making. Between the influences of globalization, the internal market and the national cultural policies, the European art market has to respond to both economic and non-economic needs; while its current state remains fragmented, basic principles of harmonization are beginning to emerge. Christa Roodt's study ${ }^{25}$ of the private international law aspects of art and cultural heritage illustrates how the lex rei sitae encounters its limits when faced with the specific challenges of the international art market. In order to avoid unjust results or even fraudulent abuse of the private international law rules, e.g. through title laundering by moving stolen items to countries with lax acquisitive prescription or good faith acquisition rules, exceptions or alternative conflicts rules need to be formulated in order to support

24 Giulio Cesare Giorgini/Sophie Perez (eds), Droit et marché de l'art en Europe: Régulation et normalisation du risque (Bruylant 2015, 299 pp.).

25 Christa Roodt, Private International Law, Art and Cultural Heritage (Edward Elgar 2015, XXIV, 391 pp.). 
restitution claims. Mara Wantuch-Thole's $\mathrm{PhD}$ thesis ${ }^{26}$ explores the possibilities of private international law as a tool in the combat against illicit trade in archaeological and cultural objects, focusing on the acquisition and protection of property rights by states and the enforcement of these sovereign rights in private law courts in recovery actions. Criticizing the situs rule for its unpredictable results and its encouragement of legal system and forum shopping, she suggests governing art recovery disputes by the lex rei sitae originis and strengthening the tendencies towards an international public policy of cultural property protection. Another $\mathrm{PhD}$ thesis scrutinizes good faith acquisition and acquisitive prescription of objects of art from a substantive law angle as Juliane Schellerer explores the demands on the buyer's diligence under German law and the DCFR. ${ }^{27}$ In these and other works, cultural property and art law theories challenge classic notions and concepts of property law both on the private international law and the substantive law level and in the national as well as the European and international context, and provide valuable food for thought.

Finally, no overview of property law publications in 2015/16 would be complete without mentioning the conference volumes of the $4^{\text {th }}$ and $5^{\text {th }}$ meetings of the Young Property Lawyers Forum. ${ }^{28}$ Based on a wide understanding of "property", the contributions by junior property lawyers provide a colourful bouquet of thought-provoking ideas mostly stemming directly from ongoing $\mathrm{PhD}$ and postdoc research projects. They cover a broad range of issues from national specialities to more global concerns and from traditional dogmatics and doctrine to newly emerging areas like virtual property law. Development lines are shown in the exploration of national reforms, historical analyses and studies on the interaction of property law with other fields of law in an ever-changing social and economic environment. Frequently, these articles by young scholars mirror larger trends in property law and indicate worthwhile areas for research, legislation and harmonization projects to turn to in the years to come. Their fresh approaches to traditional questions and their highlighting of individual, sometimes peculiar issues ensure that they will provide lively and interesting reading matter for property lawyers from all backgrounds.

26 Mara Wantuch-Thole, Cultural Property in Cross-Border Litigation: Turning Rights into Claims (De Gruyter 2015, XIX, 400 pp.).

27 Juliane Schellerer, Gutgläubiger Erwerb und Ersitzung von Kunstgegenständen (Mohr Siebeck 2016, XVII, 198 pp.).

28 Ann Apers/Sofie Bouly/Elien Dewitte/Dorothy Gruyaert (eds), Property Law Perspectives III (Intersentia 2015, XIV, 237 pp.); Dorothy Gruyaert/Eveline Ramaekers/Luke Rostill (eds), Property Law Perspectives IV (Intersentia 2016, XII, 119 pp.). 


\section{Conclusion}

The past two years have proved fruitful for international property law. Comparative studies have illustrated national developments and reforms both within general recodifications of private law and on a smaller scale, belying the prejudice of property law as static and backward-looking. It can be expected that the new trend towards comparative approaches will serve to further mutual understanding and bridge the gaps between legal systems, both in national modernization and international harmonization projects. This holds especially true for the EU context: although EU private law is still largely dominated by the law of obligations, European property law is continuing to forcefully come into its own as a discipline. The legal foundations and scope of a European regulatory competence for property law are being discussed, and it seems that some of the traditional obstacles and counterarguments against property law harmonization are gradually disappearing.

At the forefront of Europeanization are the suggestions for a harmonization regarding security rights in moveables - which due to their close relation with contract law provide a good starting point from which to branch out into other aspects of EU property law. Finding solutions for the central issue of registration which meet the approval of all member states and take into account the demands and possibilities of electronic networks and the evolving data economy will be one of the great challenges this project has to face before finally becoming reality. Synergy effects may be derived from the intensive studies on land registration which signal a new trend in comparative land law. In private international property law, critical scrutiny of the situs rule from various angles has become a recurring theme. On the whole, the development of EU property law will profit greatly from the exploration of issues at the borders of traditional property law, like its connections with public international law, and its contextualization in a world-wide environment.

It is has been impossible to do justice to the plethora of ideas, the creativity of argument and the depth of analysis that each of the works presented here brings to the field of European property law. However, readers will hopefully take this piece as a starting point for continuing their own exploration of the 2015/16 property law publications. The wealth of contributions will hopefully continue in the years to come as new research will continue to investigate the lines of thought developed so far and open up new areas for exploration, sparking ideas and projects on the national, European and international level. For 2017, some property law works have already been announced: the Common Core of European Private Law research group is working on a volume on the 
transfer of immovable property ${ }^{29}$, and a fundamental work on comparative property law by Michele Graziadei and Lionel D. Smith ${ }^{30}$ will be published as well as, of course, the second volume of von Bar's Gemeineuropäisches Sachenrecht.

29 E. Cooke/L. Martinez/A. Pradi (eds), Transfer of Immoveable Property in European Law (Cambridge University Press, forthcoming).

30 Michele Graziadei/Lionel D. Smith (eds), Comparative Property Law: Global Perspectives (Edward Elgar, forthcoming). 